\title{
Impact of marine fish cage farming on metabolism and sulfate reduction of underlying sediments
}

\author{
Marianne Holmer, Erik Kristensen
}

Institute of Biology, Odense University, DK-5230 Odense M, Denmark

\begin{abstract}
Total sediment metabolism (measured $\mathrm{CO}_{2}$ production across the sediment-water interface) and sulfate reduction (measured by ${ }^{35} \mathrm{~S}$ technique) was examined in the organic rich sediments around a marine fish cage farm in shallow Danish waters. Sediment metabolism beneath the net cages was about 10 times higher during the farming period (525 to $619 \mathrm{mmol} \mathrm{CO}_{2} \mathrm{~m}^{-2} \mathrm{~d}^{-1}$ ) than at an unaffected control station (24 to $70 \mathrm{mmol} \mathrm{CO} \mathrm{m}^{-2} \mathrm{~d}^{-1}$ ). Depth-integrated sulfate reduction rates $(0$ to $10 \mathrm{~cm}$ ) beneath the net cages ( 234 to $310 \mathrm{mmol} \mathrm{m} \mathrm{m}^{-2} \mathrm{~d}^{-1}$ ) could support 75 to $118 \%$ of the measured $\mathrm{CO}_{2}$ production across the sediment-water interface. At the end of the farming period and during winter (no fish farming), sediment metabolism and sulfate reduction rates decreased considerably 133 to $77 \mathrm{mmol}$ $\mathrm{CO}_{2} \mathrm{~m}^{-2} \mathrm{~d}^{-1}$ ), but both rates were still elevated compared to the control station, indicating that the impact of fish farming on the anaerobic mineralization was prolonged. Nearly all reduced ${ }^{35} \mathrm{~S}$ label was recovered in the acid volatile fraction (AVS). During decreasing sulfate reduction rates, however, the chromium reducible fraction (CRS) became more important in the upper oxidized sediment layers. Pore water profiles of mineralization products $\left(\mathrm{HCO}_{3}{ }^{-}\right.$and $\left.\mathrm{NH}_{4}{ }^{+}\right)$reflected the rapid decomposition and showed a preferential regeneration of nitrogen throughout fall and early spring
\end{abstract}

\section{INTRODUCTION}

Cultivation of marine fish in net cages is a growing industry with salmonids as one of the most commonly farmed species. The rapid expansion in marine fish farming during the last 20 yr has led to a growing concern about environmental impacts due to the discharge of waste products from the farms (Gowen \& Bradbury 1987. Frid \& Mercer 1989, Aure \& Stigebrandt 1990). The actual level of eutrophication in a farming area is mainly determined by site-specific properties, such as water exchange and bottom topography (Håkansson et al. 1988). The pelagic environment appears rather unaffected at most sites due to rapid dilution of waste products (Müller-Haekel 1986), whereas serious impacts on sediments and benthic communities underneath the net cages are observed frequently. Fish farm sediments are usually high in organic matter and porous due to the supply of particulate organic wastes such as food and faecal pellets. As a consequence the benthic fauna is usually quite impoverished or even depleted (Brown et al. 1987, Ye et al. 1991), and the sediment-water interface may frequently be covered with a white mat of Beggiatoa spp. (Ross 1989, Hall et al. 1990)

Only a few studies have examined the fate of particu- late organic wastes from fish farms (Kaspar et al. 1988 , Hall et al. 1990, Hansen et al. 1990, Holby 1991, Holby \& Hall 1991). These have generally revealed high sedimentation rates associated with metabolically very active sediments and rapid exchange of nutrients and gases. Decomposition of organic matter is primarily driven by anaerobic processes, and ebullition of methane is often observed (Samuelsen et al. 1988, Hall et al. 1990). Sulfate reduction, however, is generally considered the quantitatively most important terminal process for anaerobic decay of organic matter in coastal sediments when sulfate supply is sufficient (Jørgensen 1982, Skyring 1987). Rates of sulfate reduction and dynamics of reduced sulfur pools have been measured in a variety of sediments, but the general knowledge of these aspects is still insufficient in metabolically active eutrophic sediments (Skyring 1987, Thode-Andersen \& Jørgensen 1989).

The purpose of this study was to examine sediment metabolism with special emphasis on sulfate reduction, in the organic rich sediments around a net cage farm in the shallow Kolding Fjord, Denmark. Benthic metabolism $\left(\mathrm{CO}_{2}\right.$ production and dissolved nitrogen flux across the sediment water interface), and sulfate reduction were followed during $1 \mathrm{yr}$. The results were evaluated in relation to the physical and chemical environment 
(organic content, pore water profiles of dissolved nitrogen, sulfate, alkalinity, etc.). The results form a preliminary basis for the assessment of carbon, sulfur and nitrogen dynamics in organic rich fish farm sediments in shallow water.

\section{MATERIALS AND METHODS}

Study site. Sediment was sampled on 6 occasions from May 1989 until March 1990 around a marine fish farm situated in Kolding Fjord, Denmark (Fig. 1). Rainbow trout Oncorhynchus mykiss have been cultured in the farm since 1982 with a yearly net production around $80 \mathrm{t}$. The trout were fed manually, and in the studied farming season the effective food conversion coefficient was 1.3 [the ratio between food input and net fish production, where net production was defined as gross production (including escaped and dead fish) minus juveniles]. In 1989 the farm contained 13 net cages: 6 circular, diameter $(d)=15.9 \mathrm{~m} ; 5$ circular, $d=$ $12.7 \mathrm{~m}$; and 2 squared, length $=7.5 \mathrm{~m}$.

Water depth in the farming area was ca $5 \mathrm{~m}$ and the distance between the bottom of net cages and sediment was ca $1 \mathrm{~m}$. Water currents at the site were sufficient to keep well-oxygenated conditions around the farm throughout the year. However, during high water temperatures and high fish production, lowered oxygen concentrations were occasionally measured near the sediment surface. Water temperature ranged from 4 to $20{ }^{\circ} \mathrm{C}$, and salinity varied between 8 and $27 \%$ depending upon the wind-driven water exchange between Kolding Fjord (low salinity) and Lillebælt (high salinity).

Two stations were examined at the fish farm, Stn 1 underneath a square net cage and Stn 2, a control station situated $30 \mathrm{~m}$ away from the farming area (preliminary samplings have shown that this station

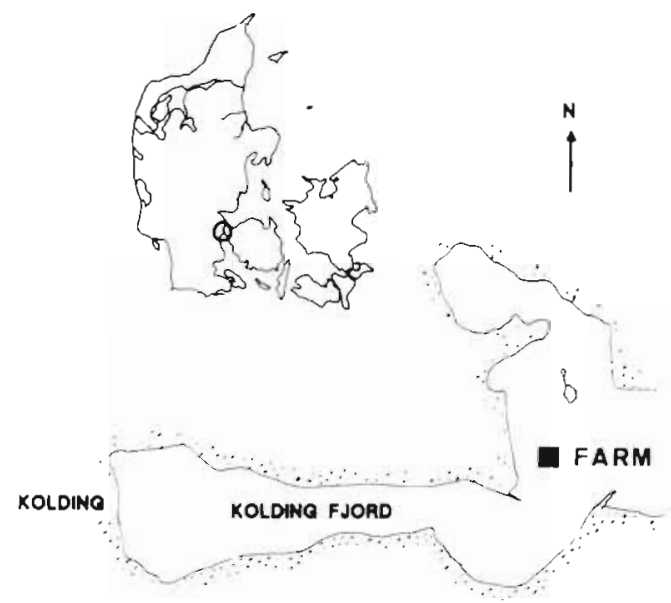

Fig. 1. Location of fish farm in $1989\left(55^{\circ} 30^{\prime} 22^{\prime \prime} \mathrm{N}, 9^{\circ} 35^{\prime} 74^{\prime \prime} \mathrm{E}\right)$ remains unaffected by the farming activity). The orqanic-rich sediment at Stn 1 was devoid of macrofauna throughout the study period. Shortly after initiation of the farming season a white cover of Beggiatoa spp. evolved at the sediment-water interface. Later in the season the sediment surface turned completely black indicating that anoxic conditions prevailed in the water close to the bottom at this time. At Stn 2 the upper sediment layers were oxidized throughout the sampling period allowing the presence of an abundant benthic macrofauna (e.g. Corbula gibba, Cardium sp., Macoma baltica, Mysella bidentata, Nephtys hombergii).

Sampling procedures. Sediment cores for solid phase analysis and pore water extractions were collected with $5.2 \mathrm{~cm}$ interior diameter (i.d.) acrylic core liners. Cores for flux incubations were sampled with $8.0 \mathrm{~cm}$ i.d. core liners, while $2.6 \mathrm{~cm}$ i.d. core liners with silicone-filled injection ports were used for the sulfate reduction assays and determination of reduced inorganic sulfur pools. Cores were sampled directly below a net cage by diving, most frequently during intensive farming in late summer and autumn.

Sulfate reduction and inorganic sulfur pools. Sulfate reduction was determined in $1 \mathrm{~cm}$ intervals to $10 \mathrm{~cm}$ depth in duplicate cores from the 2 stations. A volume of $2 \mu \mathrm{l}$ carrier-free ${ }^{35} \mathrm{~S}_{-} \mathrm{SO}_{4}{ }^{2-}$ solution $(72 \mathrm{kBq})$ was injected through the silicone ports at each depth. Cores from Stn 1 were incubated in the dark for $6 \mathrm{~h}$ and cores from Stn 2 for $18 \mathrm{~h}$ at in situ temperatures. Continuous supply of sulfate during incubation was obtained from $1 \mathrm{~cm}$ of overlying seawater. Subsequently, the sediment was extruded stepwise and cut in $1 \mathrm{~cm}$ segments. These were immediately fixed in $20 \% \operatorname{ZnAC}(1: 1$ volume) and frozen. Separations of reduced sulfur compounds were performed by the 2 step distillation procedure of Fossing \& Jørgensen (1989): Step 1 liberates acid volatile sulfides (AVS) and Step 2 chromium reducible sulfur (CRS). AVS is operationally defined as hydrogen sulfide $\left(\Sigma \mathrm{HS}^{-}: \mathrm{H}_{2} \mathrm{~S}\right.$ $+\mathrm{HS}^{-}+\mathrm{S}^{2-}$ ) and FeS, and $\mathrm{CRS}$ as pyrite $\left(\mathrm{FeS}_{2}\right)$ and elemental sulfur $\left(\mathrm{S}^{0}\right)$.

Sediment samples were washed 3 times in tracerfree seawater to remove ${ }^{35} \mathrm{~S}-\mathrm{SO}_{4}{ }^{2-}$ before distillation. About $1 \mathrm{~g}$ of the washed sediment pellet was transferred to a reaction flask containing $10 \mathrm{ml} 50 \%$ ethanol. After degassing with $\mathrm{N}_{2}$ for 10 to $15 \mathrm{~min}$, the slurry was acidified with $8 \mathrm{ml} 12 \mathrm{M} \mathrm{HCl}$. AVS was liberated as $\mathrm{H}_{2} \mathrm{~S}$ at room temperature under continuous stirring for $30 \mathrm{~min}$ and trapped as $\mathrm{ZnS}$ in $10 \mathrm{ml} 5 \%$ buffered ZnAc. CRS was extracted from the sediment slurry remaining after the AVS distillation. A new ZnAc trap was inserted and $16 \mathrm{ml} 1 \mathrm{M} \mathrm{Cr}^{2+}$ in $0.5 \mathrm{M} \mathrm{HCl}$ was added before distillation was resumed by $30 \mathrm{~min}$ of boiling. Subsamples of suspended ZnS from the traps 
were mixed with Instagel scintillation liquid and radioactivity was counted on a Packard Tri-carb 2200 Liquid Scintillation Analyzer.

Time-course control experiments revealed that sulfate reduction in subsurface sediment ( 3 to $10 \mathrm{~cm}$ ) at Stn 1 remained constant for incubation periods of 4 to $24 \mathrm{~h}$. In surface sediment $(0$ to $3 \mathrm{~cm}$ ), however, the reduction rates decreased with time probably due to diffusion loss and reoxidation of labelled sulfide during incubation. Similar non-linearity has previously been found in surface sediments (Jørgensen 1978, ThodeAndersen \& Jørgensen 1989). Zero contamination determined by injection of label in cores at $0^{\circ} \mathrm{C}$, followed by immediate slicing and fixing, was found to be insignificant. The precision of rate measurements was within 5 to $8 \%$.

The pool sizes of reduced inorganic sulfur species were determined from the AVS and CRS distillation traps. Sulfide was analysed in duplicates by the methylene blue technique of Cline (1969). Elemental sulfur, $\mathrm{S}^{0}$, was extracted once (in spring 1990) by the $\mathrm{CS}_{2}$ method of Troelsen \& Jørgensen (1982).

Benthic fluxes. Sediment metabolism was measured as total $\mathrm{CO}_{2}\left(\mathrm{TCO}_{2}\right)$ production and exchange of dissolved inorganic nitrogen (DIN) in undisturbed sediment cores $(\mathrm{d}=8.0 \mathrm{~cm})$. At each sampling date 3 cores from Stns $1 \& 2$ were acclimated in the dark at in situ temperatures for $2 \mathrm{~d}$. The overlying water (ca 0.5 l) was continuously recycled from a tank containing ca 1001 seawater obtained at the locality. Oxygen concentrations in the cores were always close to saturation and DIN concentrations were kept low at in situ level $\left(<10 \mu \mathrm{M} \mathrm{NH}_{4}{ }^{+} ;<1 \mu \mathrm{M} \mathrm{NO}_{2}{ }^{-}+\mathrm{NO}_{3}{ }^{-}\right)$. During flux incubations the water flow was temporarily interrupted and all cores were equipped with stirrer motors which maintained a continuous water circulation at a rate just below resuspension limit. Fluxes were determined from the concentration difference between initial and final samples during incubation periods of 0.5 to $3 \mathrm{~h}$ (10 to $30 \%$ decline in oxygen concentration). Nutrient samples were filtered (GF/C) and stored frozen until analysis. $\mathrm{TCO}_{2}$ was analyzed within $6 \mathrm{~h}$ after sampling by potentiometric Gran titration $\left(C_{T}=V_{2}-V_{1}\right)$ (Talling 1973). The precision of this method was within $3 \%$. DIN was analyzed within 1 to 3 mo using the standard autoanalyzer methods of Armstrong et al. (1967) for $\mathrm{NO}_{2}{ }^{-}$and $\mathrm{NO}_{3}{ }^{-}$, and Solarzano (1969) for $\mathrm{NH}_{4}{ }^{+}$.

Sediment characteristics. Density was calculated from the weight and volume of wet sediment. Water content was determined after drying the sediment samples overnight at $105^{\circ} \mathrm{C}$. The organic content was measured as loss-on-ignition (LOI) at $520^{\circ} \mathrm{C}$ for $6 \mathrm{~h}$, and as particulate organic carbon (POC) and nitrogen (PON) after the method of Kristensen \&
Andersen (1987) using a Hewlett-Packard 185B CHN Analyzer.

Pore water. Pore water was obtained from 2 replicate cores by centrifuging for $5 \mathrm{~min}$ at $3000 \mathrm{rpm}$. No attempt was made to prevent loss of pore water sulfides (pw$\mathrm{H}_{2} \mathrm{~S}$ ) due to oxidation and diffusion. Alkalinity was measured within $24 \mathrm{~h}$ by potentiometric titration with $0.01 \mathrm{M} \mathrm{HCl}$ following the procedures of Edmond (1970). $\mathrm{Pw}-\mathrm{H}_{2} \mathrm{~S}$ interferes significantly with this method, and the presence of $\mathrm{pw}-\mathrm{H}_{2} \mathrm{~S}$ was routinely measured during sample preparation and was always found to be low. It was assumed that $\mathrm{pw}-\mathrm{H}_{2} \mathrm{~S}$ was lost by diffusion and oxidation to sulfate. However, incomplete oxidation products, e.g. $\mathrm{SO}_{3}{ }^{2-}$ and $\mathrm{S}_{2} \mathrm{O}_{3}{ }^{2-}$, may contribute to the alkalinity. The maximum error of the measurements was 5 to $10 \%$, if all pw- $\mathrm{H}_{2} \mathrm{~S}$ was incompletely oxidised. Sulfate was analyzed by ion liquid chromatography and UV-detection on a Kontron Ion Liquid Chromatograph with $2.5 \mathrm{mM}$ potassium hydrogen phthalate ( $\mathrm{pH}=4.5$ ) as eluent. Samples for DIN were frozen immediately and analyzed within 1 to 3 mo as previously described.

\section{RESULTS}

The farming season of 1989 began in early spring and ended in late October. The trout biomass increased slowly until early June followed by a more rapid, but steady increase until the end of the farming period (Fig. 2B) The sudden drop in August reflected a $25 \%$ harvest of the trout biomass. Input of food increased rapidly in April and May and remained with some deviations at a high level throughout the summer, followed by a continual decrease from August until the end of the farming period (Fig. 2C). In November 1989, net cages were moved to the land and farming was restarted in spring of 1990 .

\section{Sediment}

The sediment at Stn 1 was rich in organic matter, ranging from up to $23 \%$ (loss-on-ignition, LOI) in the top most layer $(0$ to $1 \mathrm{~cm}$ ) followed by a decrease to 16 to $17 \%$ at $6 \mathrm{~cm}$. High LOI (18 to $21 \%$ ) was found in the deeper parts at both stations (Table 1). At Stn 1 organic content in the upper 0 to $2 \mathrm{~cm}$ increased during the farming season, and was up to $50 \%$ higher in the 0 to $1 \mathrm{~cm}$ interval compared to that found at Stn 2 in October. At this latter station the organic content remained constant throughout the sampling period. The organic rich upper layer at Stn 1 apparently disappeared during winter as no major difference was found between the 2 stations in March 1990 (Table 1). 

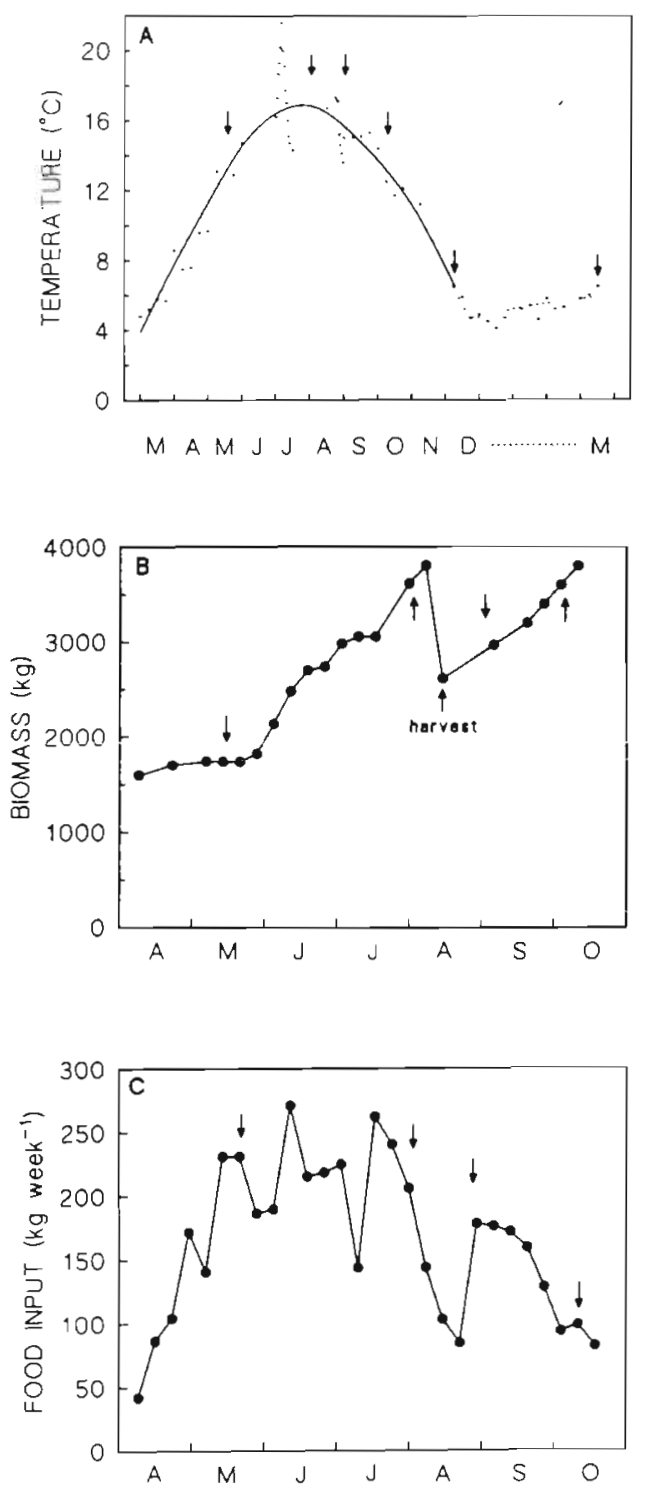

Fig. 2. (A) Seasonal variation in water temperature (smooth curve fitted by eye). Winter temperatures (dotted line) are reported from Lillebælt. (B) Time pattern of trout biomass in examined net cage. (C) Temporal variation in food input to examined net cage. Arrows indicate time of sediment sampling

\section{Sulfate reduction and inorganic sulfur pools}

Sulfate reduction rate (SRR) in the sediment at Strn 1 was most intense during summer, with $99 \%$ of the total depth-integrated activity $(0$ to $10 \mathrm{~cm})$ occurring in the upper $4 \mathrm{~cm}$ (Fig. 3). At the end of the farming season when sulfate reduction rates had declined, changes were most dramatic in this upper layer, i. e. from 5 to $8 \mu \mathrm{mol} \mathrm{cm} \mathrm{cm}^{-3} \mathrm{~d}^{-1}$ in September to 0.7 to $2 \mu \mathrm{mol} \mathrm{cm} \mathrm{cm}^{-3} \mathrm{~d}^{-1}$ in October. During winter and early spring these rates
(0 to $4 \mathrm{~cm}$ ) decreased further to 107 to $190 \mathrm{nmol} \mathrm{cm}^{-3}$ $\mathrm{d}^{-1}$, and only $64 \%$ of the total sulfate reduction occurred in this layer. SRR in the uppermost layers at Stn 2 were generally much lower than those found in the same interval at $\operatorname{Stn} 1$ (Fig. 3). The rates measured below $4 \mathrm{~cm}$ at $\operatorname{Stn} 2$ were lower than those above (except in November), but similar to rates in the deeper parts (i. e. below $4 \mathrm{~cm}$ ) at Stn 1 .

The partition of radiolabel into acid volatile sulfides $\left(S_{\text {Avs }}\right)$ and chromium reducible sulfur (SRR $\left.R_{C R S}\right)$ appeared relatively constant at Stn 1 during the period from May to November. Almost all label (>80\%) was recovered as $\mathrm{AV}^{35} \mathrm{~S}$ in the upper $4 \mathrm{~cm}$ of the sediment (Fig. 3). In the deeper and less active layers, the importance of $\mathrm{SRR}_{\mathrm{AVS}}$ was less marked and in most cases dropped to approximately $50 \%$ at 8 to $10 \mathrm{~cm}$. In spring $S_{\text {SR }}$ Av accounted for 50 to $75 \%$ of SRR with no specific depth pattern. At Stn 2 the $S_{\text {RR }}$ Avs contribution in the upper 0 to $3 \mathrm{~cm}$ was generally much less than $50 \%$, followed by a gradual, but irregular, increase with depth to about $50 \%$.

Total reduced inorganic sulfur pools were separated into AVS ( $\left.P_{A V S}\right), C R S\left(P_{C R S}\right)$, and on 1 occasion into elemental sulfur, $\mathrm{S}^{0}$. The concentration of $\mathrm{S}^{0}$, however, accounted for less than $1 \%$ of $P_{C R S}$ indicating that pyrite, $\mathrm{FeS}_{2}$, dominated the chromium reducible sulfur pool. $\mathrm{FeS}_{2}$ appeared to be the largest pool at both stations, 8 to $16 \mathrm{~mol} \mathrm{~m}^{-2}$, accounting for 94 to $98 \%$ of the total reduced inorganic sulfur pool at Stn 2, and 65 to $88 \%$ at Stn 1 (Table 2). The concentration of $\mathrm{FeS}_{2}$ increased with depth at both stations with a maximum pool of 175 to $200 \mu \mathrm{mol} \mathrm{cm}^{-3}$, whereas the AVS pool showed a subsurface maximum at 1 to $5 \mathrm{~cm}$ depth (max. $75 \mu \mathrm{mol} \mathrm{cm} \mathrm{cm}^{-3}$ at Stn 1 and $29 \mu \mathrm{mol} \mathrm{cm}{ }^{-3}$ at Stn 2).

\section{Sediment metabolism}

$\mathrm{CO}_{2}$ production, $\mathrm{J}\left(\mathrm{CO}_{2}\right)$, and depth-integrated sulfate reduction rates, $\Sigma S R R$, were high at $\operatorname{Stn} 1$ during the farming season (Fig. 4). J(C $\left.\mathrm{CO}_{2}\right)$ ranged from 525 to 619 $\mathrm{mmol} \mathrm{m} \mathrm{m}^{-2} \mathrm{~d}^{-1}$ and $\Sigma$ SRR ranged from 234 to $310 \mathrm{mmol}$ $\mathrm{m}^{-2} \mathrm{~d}^{-1}$. These rates were 10 to 20 times higher than the rates obtained at Stn 2 (Fig. 4). At the end of the farming period (in October) sediment metabolism at Stn 1 declined rapidly to a quarter of the summer rates followed by a slow decline during winter, attaining $\mathrm{J}\left(\mathrm{CO}_{2}\right)$ values in March of 33 to $77 \mathrm{mmol} \mathrm{m}^{-2} \mathrm{~d}^{-1}$ and for $\Sigma \mathrm{SRR}$ of 9 to $34 \mathrm{mmol} \mathrm{m}^{-2} \mathrm{~d}^{-1}$. Sediment metabolism, however, remained elevated compared to Stn 2 throughout the sampling period. At both stations $\mathrm{J}\left(\mathrm{CO}_{2}\right)$ and $\Sigma \mathrm{SRR}$ largely followed the seasonal variation in water temperature (Fig. 2A) exhibiting apparent $Q_{10}\left(6\right.$ to $\left.17^{\circ} \mathrm{C}\right)$ values of 14.9 and 13.1 at $\operatorname{Stn} 1$ and 3.0 and 3.5 at $\operatorname{Stn} 2$, respectively. An exception to the general temperature 
Table 1. Depth profiles of sediment organic content presented as loss-on-ignition (LOI), particulate organic carbon (POC) and particulate organic nitrogen (PON) at 2 sampling stations. Values are given in \% dry weight

\begin{tabular}{|c|c|c|c|c|c|c|c|c|c|}
\hline \multirow{2}{*}{$\begin{array}{l}\text { Depth } \\
(\mathrm{cm})\end{array}$} & \multicolumn{3}{|c|}{ May/June } & \multicolumn{3}{|c|}{ October } & \multicolumn{3}{|c|}{ March } \\
\hline & LOI & POC & PON & LOI & $\mathrm{POC}$ & PON & LOI & POC & PON \\
\hline \multicolumn{10}{|c|}{ Station 1} \\
\hline $0-1$ & 21.27 & 7.48 & 0.99 & 23.53 & 7.72 & 1.25 & 18.22 & 5.85 & 0.74 \\
\hline $1-2$ & 16.20 & 4.60 & 0.57 & 17.09 & 5.97 & 0.86 & 17.19 & 5.74 & 0.75 \\
\hline $2-3$ & 16.90 & 4.36 & 0.53 & 15.36 & 4.99 & 0.64 & 16.00 & 5.06 & 0.70 \\
\hline $3-4$ & 16.18 & 4.06 & 0.50 & 14.35 & 4.09 & 0.46 & 15.76 & 4.69 & 0.61 \\
\hline $4-6$ & 17.63 & 4.69 & 0.56 & 17.13 & 4.98 & 0.60 & 14.76 & 4.35 & 0.60 \\
\hline $6-8$ & 20.83 & 6.20 & 0.71 & 20.92 & 5.76 & 0.70 & 17.66 & 5.71 & 0.70 \\
\hline $8-10$ & 21.82 & 6.34 & 0.75 & 21.91 & 6.47 & 0.79 & 20.20 & 6.46 & 0.78 \\
\hline \multicolumn{10}{|c|}{ Station 2} \\
\hline $0-1$ & 16.55 & 5.37 & 0.65 & 15.45 & 5.03 & 0.51 & 15.55 & 5.05 & 0.65 \\
\hline $1-2$ & 16.23 & 4.91 & 0.57 & 16.46 & 5.36 & 0.60 & 15.18 & 4.80 & 0.62 \\
\hline $2-3$ & 15.58 & 4.48 & 0.56 & 16.65 & 5.15 & 0.63 & 15.02 & 4.97 & 0.64 \\
\hline $3-4$ & 15.98 & 5.24 & 0.49 & 17.78 & 5.38 & 0.62 & 14.66 & 4.80 & 0.63 \\
\hline $4-6$ & 17.41 & 5.21 & 0.58 & 18.15 & 5.66 & 0.66 & 14.67 & 4.77 & 0.64 \\
\hline $6-8$ & 17.85 & 5.86 & 0.66 & 18.32 & 5.59 & 0.67 & 17.67 & 5.97 & 0.74 \\
\hline $8-10$ & 17.91 & 5.79 & 0.61 & 18.76 & 5.59 & 0.67 & 19.10 & 6.55 & 0.78 \\
\hline
\end{tabular}
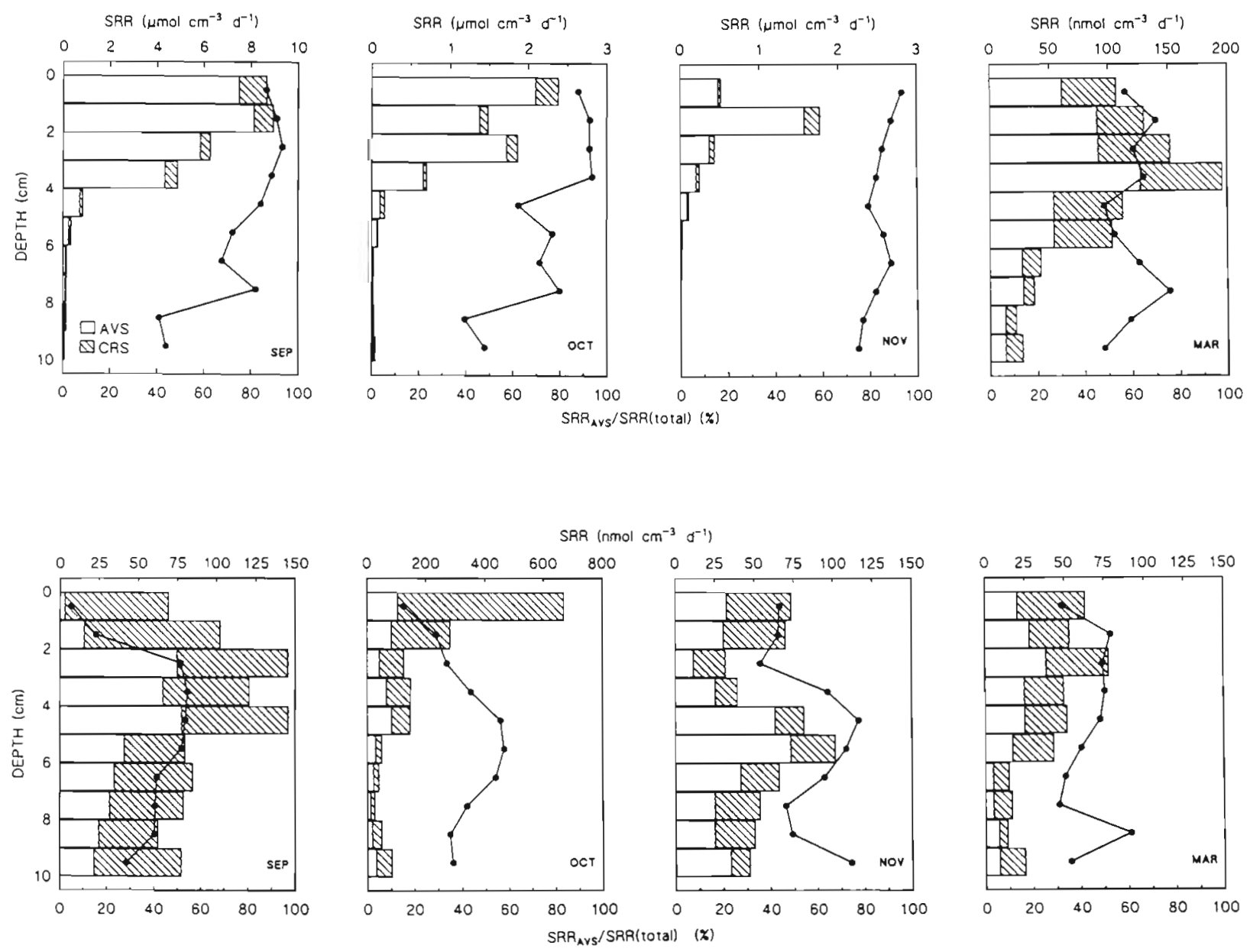

Fig. 3. Depth distribution of sulfate reduction rates (SRR) at Stns 1 (upper) and 2 (lower) in September, October, November and March. Bars indicate the relative recoveries of reduced ${ }^{35} \mathrm{~S}$ in the AVS and CRS pool. Line graph shows contribution of AVS as $\%$ of total sulfate reduction $\left(S_{R R}\right.$ total $\left.=S_{R R} R_{A V S}+S R R_{C R S}\right)$. Note change in units for $S R R$ at both stations 
Table 2. Percentage of labelled reduced sulfur recovered as acid volatile sulfides (\%AVS ) (integrated from $0-10 \mathrm{~cm}$ ) and AVS pool for total reduced sulfur pool ( $\%$ AVS $_{\mathrm{p}}$ )

\begin{tabular}{|lcccc|}
\hline \multirow{2}{*}{ Date } & \multicolumn{2}{c}{$\operatorname{Stn} 1$} & \multicolumn{2}{c|}{ Stn 2 } \\
& \% AVS & \% AVS & \% AVS $_{\mathrm{R}}$ & \% AVS \\
\hline Sep & 87.3 & 19.3 & 36.1 & 2.4 \\
Oct & 91.0 & 16.7 & 29.9 & 4.6 \\
Nov & 80.4 & 35.8 & 56.0 & 2.1 \\
Mar & 47.0 & 12.2 & 44.6 & 6.3 \\
\hline
\end{tabular}

dependence was observed at Stn 2 in October, where sulfate reduction actually increased despite decreasing temperatures and declining $\mathrm{CO}_{2}$ production.

The contribution of sulfate reduction to total sediment metabolism was estimated using a conversion ratio of 2:1 (2 moles of $\mathrm{CO}_{2}$ produced per mole $\mathrm{SO}_{4}{ }^{2-}$ reduced). Sulfate reduction was responsible for the vast majority of sediment metabolism at Stn 1 particularly during the farming season (Table 3), where $\Sigma$ SRR accounted for 75 to $118 \%$ of the measured $\mathrm{CO}_{2}$ production. Lower values corresponding to those generally found at Stn 2 (25 to $61 \%$ ) were only attained at this station in March.

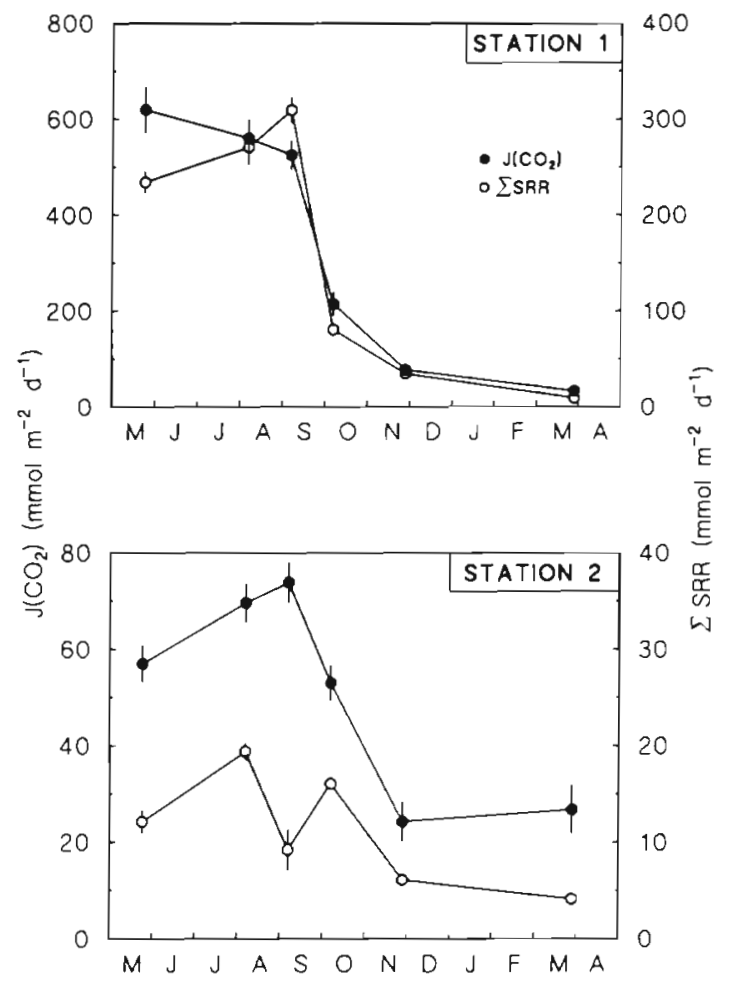

Fig. 4. Temporal pattern of $\mathrm{CO}_{2}$ production, $\mathrm{J}\left(\mathrm{CO}_{2}\right)$, and depth integrated sulfate reduction, $\Sigma \mathrm{SRR}$. J $\left(\mathrm{CO}_{2}\right)$ : mean of 3 cores $\pm \mathrm{SE}$; $\Sigma \mathrm{SRR}$ : mean of 2 cores \pm range

\section{Pore water chemistry}

The high metabolic activity at Stn 1 during the farming season was reflected in the pore water profiles. Sulfate showed a marked decrease with depth (lowest concentration seen at $4 \mathrm{~cm}$ ) followed by a gradual rise in concentration below $4 \mathrm{~cm}$. No such sulfate depletion was evident at Stn 1 in spring or at Stn 2 throughout the sampling period (Fig. 5A, B). The subsurface peaks and generally higher level observed in March at both stations were probably caused by temporal salinity variations in the overlying water masses.

The profiles of pore water alkalinity and $\mathrm{NH}_{4}{ }^{+}$at Stn 1 increased dramatically with depth during the farming period reaching a maximum in October of $28 \mathrm{meq} \mathrm{l}^{-1}$ and $2.7 \mathrm{mM}$ at 4 to $6 \mathrm{~cm}$ with no further changes below (Fig, 5C to F). In March, the concentrations of these solutes were generally much lower at both stations, showing a gradual increase with depth to 3 to $4.5 \mathrm{meq} 1^{-1}$ and 0.10 to $0.27 \mathrm{mM}$. The concentrations of $\mathrm{NO}_{3}{ }^{-}$and $\mathrm{NO}_{2}{ }^{-}$were low $(<1 \mu \mathrm{M})$ at both stations throughout the sampling period.

\section{DISCUSSION}

The Kolding Fjord fish farm markedly affects the sediment below the net cages while no changes were observed at a distance of $30 \mathrm{~m}$ from the outermost frame. During a pilot study of a transect from the farm, impacts (elevated sediment metabolism, elevated organic content, bottom fauna deterioration) were seen over a distance of $5 \mathrm{~m}$ from the outermost frame (data not shown). A similar limited-area distribution of accumulated organic matter associated with marine fish farms has previously been found (Brown et al. 1987, Gowen \& Bradbury 1987, Hall et al. 1990, Ye et al. 1991). The short distance between the bottom of the net cages and the sea floor prevents reliable measurements of sedimentation rates at the present loca-

Table 3. Estimated $\mathrm{CO}_{2}$ production based on measured depthintegrated sulfate reduction rates $(2 \times \Sigma$ SRR $)$ presented as percentage of measured $\mathrm{CO}_{2}$ production $\mathrm{J}\left(\mathrm{CO}_{2}\right)$ from sediment incubations

\begin{tabular}{lrr}
\hline Date & \multicolumn{2}{c}{$\% \mathrm{CO}_{2}$} \\
& Stn 1 & Stn 2 \\
\hline May/Jun & 75.5 & 42.5 \\
Aug & 96.6 & 55.8 \\
Sep & 118.0 & 24.9 \\
Oct & 74.9 & 60.8 \\
Nov & 89.6 & 50.2 \\
Mar & 54.6 & 30.6 \\
\hline
\end{tabular}



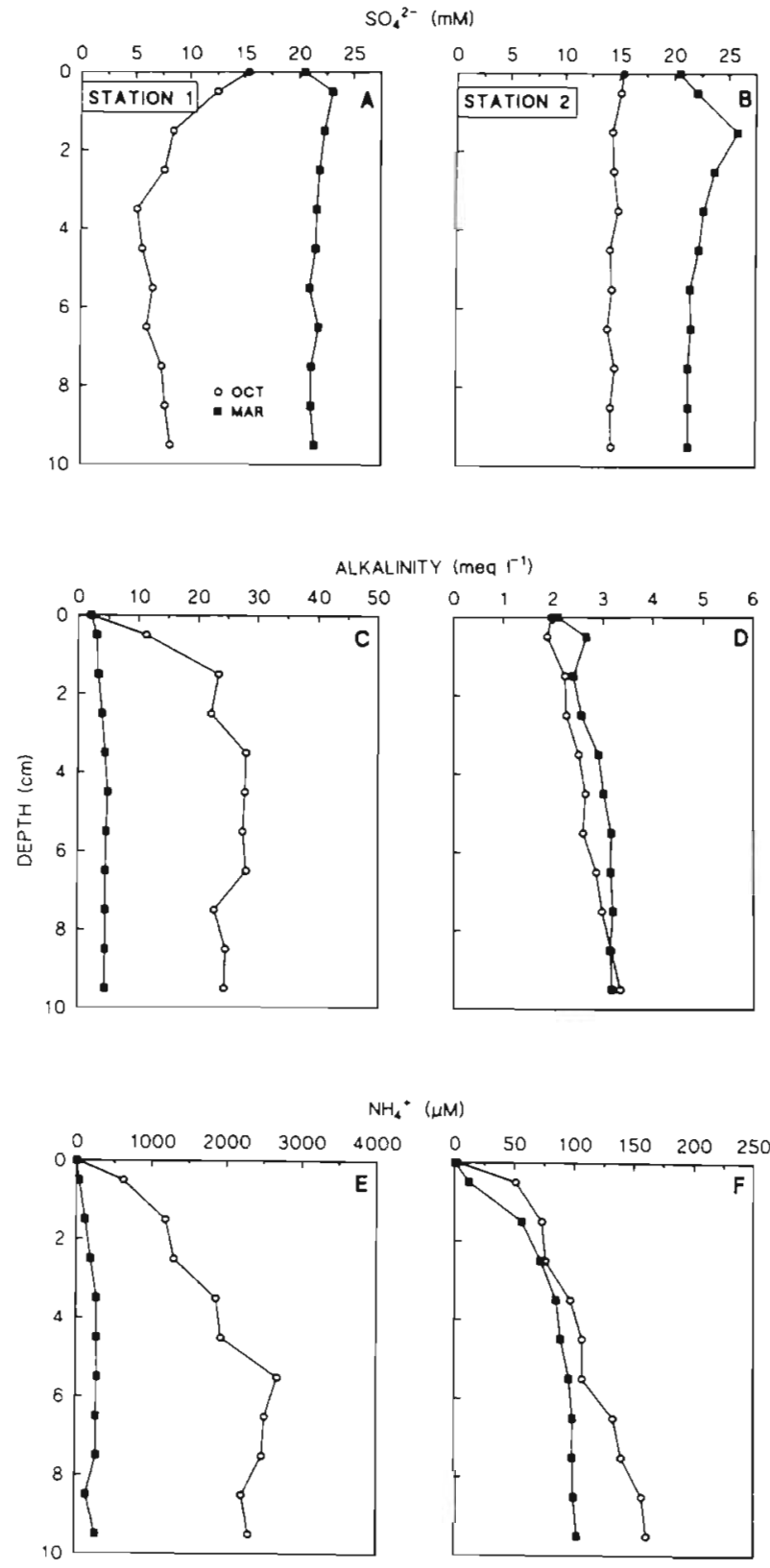

Fig. 5. Depth profiles of sulfate $\left(\mathrm{SO}_{4}{ }^{2-}\right)$, alkalinity and ammonium $\left(\mathrm{NH}_{4}{ }^{+}\right)$at $\operatorname{Stn} 1(\mathrm{~A}, \mathrm{C}, \mathrm{E})$ and $\operatorname{Stn} 2(\mathrm{~B}, \mathrm{D}, \mathrm{F})$ in October and March. Values at depth $=0 \mathrm{~cm}$ indicate the overlying water

tion. Input of organic matter during farming is evident however as elevated organic content was measured in the upper 0 to $2 \mathrm{~cm}$ of the farm sediment, whereas in spring the organic content appeared similar to the control station (Table 1). These observations imply that resuspension of surface sediment by strong currents and wave action during winter storms may resuspend and remove most of the accumulated organic matter. Additionally, the cultivation scheme with no trout production in winter prevents any new accumulation of waste products during this period. Long-term deposits of waste products beneath fish farms are often found at locations with slow water currents and deep waters e. g. at sheltered sites and in fjords with basin water (sill fjords). Aure \& Stigebrandt (1990) found that the mass (thickness) of accumulated wastes at fish farms located in sill fjords, where no erosion or transportation of sediments occurs, reaches an equilibrium after a few decades of fish production. Deposited material at these sites is only removed by biological processes, and the rate of decomposition appears to be proportional to the mass of organic matter with approximately $10 \%$ of the entire pool being mineralized annually. The organic content is typically on the order of 30 to $40 \%$ dry weight (LOI) in such sediments (Hansen et al. 1990).

\section{Sediment metabolism}

The metabolism in eutrophic fish farm sediment is dominated by anaerobic decomposition processes. Visual observations indicate that during farming the sediment is highly reduced and that the penetration of oxygen is generally low. Rates of $\mathrm{CO}_{2}$ production at Stn 1 (Fig. 4A) are similar to production rates obtained at other marine fish farms (Hall et al. 1990), and depthintegrated sulfate reduction in the same order of magnitude as presented here has also previously been reported for eutrophic fishponds $\left(\Sigma S R R_{A v S}\right.$ Blackburn et al. 1988) and under experimental conditions (Sampou \& Oviatt 1991). Sediment metabolism during farming is, however, up to 10 times higher than usually found in coastal areas (Crill \& Martens 1987, Skyring 1987, Mackin \& Swider 1989, Swider \& Mackin 1989, Thode-Andersen \& Jørgensen 1989).

The temporal variation observed for both $\mathrm{CO}_{2}$ production and depth-integrated sulfate reduction at Stn 1 was much more dramatic than at Stn 2. Seasonal changes in sediment metabolism are often explained from variations in temperature by applying $Q_{10}$ values for the microbial community of 2 to 3 (Jørgsensen \& Sørensen 1985, Westrich $\&$ Berner 1988). In the present fish farm sediment, however, such a temperature dependence does not fully explain the observed seasonal variations, since the apparent $Q_{10}$ at Stn 1 is nearly 4 times higher than found at Stn 2 and in other unaffected coastal sediments (Crill \& Martens 1987. Mackin \& Swider 1989). Mineralization rates in sediments are generally very dependent upon the quantity of organic matter (Jørgensen 1982, Westrich \& Berner 1984). Accordingly, the input of labile food material and sediment metabolism in the present study were highly correlated (Fig.6). This indicates that seasonal 
changes in mineralization rates are largely controlled by the input of waste products to the sediment. Temperature can thus only explain approximately $40 \%$ of the temporal variation at Stn 1 , when applying a $Q_{10}$ value similar to the one obtained at the control station. The remainder appears to be due to variations in food input, which in turn is highly correlated with temperature. An analogous trend with increased sediment metabolism independent of temperature changes, although less pronounced than found here, has been reported for coastal areas during sedimentation of spring and autumn blooms and in simulated laboratory experiments (Kelly \& Nixon 1984, Graf 1987, Sampou \& Oviatt 1991, Henrik Fossing pers. comm.). The continued decline in benthic metabolism during winter at constant low temperatures is probably caused by storm removal and continued decay of the labile organic waste which was deposited during the previous farming period (Fig. 4). In spring, however, sediment metabolism at Stn 1 still remained highes than at the control station. The subsurface maximum of SRR found in the 1 to $5 \mathrm{~cm}$ depth interval of fish farm sediment (Fig. 3) indicated that labile organic substrates were still present at this time. A similar long-term effect on sediment metabolism after a pulse-input of organic matter has previously been found in laboratory mesocosms (Kelly \& Nixon 1984).

Eutrophic marine sediments and fish farm sediments are generally characterized by sulfate depletion and methane production close to the sediment surface (Martens \& Klump 1984, Samuelsen et al. 1988, Hall et al. 1990, Kuivila et al. 1990). This is also found at the present location during recent investigations (Holmer unpubl.); but in the 1989-90 season, no such gas production was observed and pore water sulfate always remained $>3 \mathrm{mM}$. Sulfate reduction rates are independent of the sulfate concentration at this level (Boudreau \& Westrich 1984). Concurrently the importance of sul-

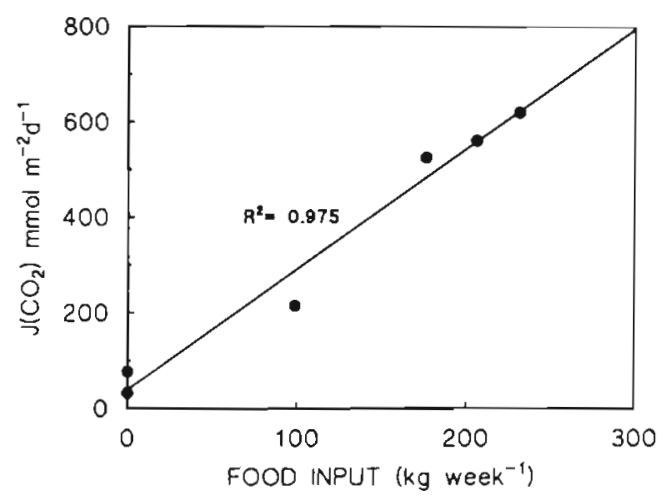

Fig. 6. Relationship between sediment metabolism (measured as $\mathrm{CO}_{2}$ production) and weekly food input to examined net cage. Line represents best fit by linear regression analysis fate reduction for the decomposition of organic matter, measured as $\mathrm{CO}_{2}$ production, was prominent 75 to $118 \%$ ) during farming (Table 3 ). Sulfate reduction usually accounts for around $50 \%$ of the total respiration in unaffected coastal sediments (Jørgensen 1982, Chanton et al. 1987), but may be as high as $85 \%$ (Mackin \& Swider 1989. Sampou \& Oviatt 1991). At the control station in the present study, sulfate reduction appeared to be responsible for 25 to $61 \%$ of the sediment metabolism.

\section{Inorganic sulfur pools}

The recovery of ${ }^{35} \mathrm{~S}$ in the various reduced sulfur pools (AVS and $\mathrm{FeS}_{2}$ ) remained relatively constant at Stn 1 during the farming season (Fig. 3). Thus, the ratio between the acid volatile sulfur pool and the pool of pyrite is generally high $(>1: 10)$ with ${ }^{35} \mathrm{~S}$ mainly being

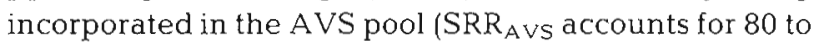
$91 \%$ of the total sulfate reduction rate). This partition is in accordance with the results of Thode-Andersen \& Jørgensen (1989) from metabolically active sediments. In spring, when total sediment metabolism had declined to approximately $1 / 20$ of the peak activity during farming, a shift occurred with a relative larger proportion of label being recovered from the $\mathrm{FeS}_{2}$ pool. The depth profiles of $S R R_{A v S}$ below the net cages changed from a surface-maximum during farming to a subsurface-maximum during winter, and these changes agree with the general pattern found in coastal sediments: decreasing metabolic activity due to lower sedimentation (organic input) allow for deeper penetration of oxidized compounds $\mathrm{O}_{2}, \mathrm{NO}_{3}{ }^{-}$, $\mathrm{Fe}^{3+}$, etc.) and consequently diminished the role of SRR $_{\text {AvS }}$ in the upper layers (Martens \& Klump 1984, Crill \& Martens 1987).

The sediment at Stn 2 can be characterized as an oxidized and relatively low activity environment (sensu Thode-Andersen \& Jørgensen 1989) with a low ratio between the pools of AVS and pyrite $(<1: 20)$. Accordingly, these conditions prevailed even during the very high sulfate reduction rate at 0 to $1 \mathrm{~cm}$ in October (probably due to mixing or resuspension of the sediment), and sulfate reduction was characterized by the high incorporation in the CRS-pool.

\section{Carbon and nitrogen dynamics in the sediment}

Mineralization in the upper 0 to $4 \mathrm{~cm}$ of sediment at Stn 1 was stimulated throughout the farming season with dramatic effects on pore water chemistry 10 to $10 \mathrm{~cm}$ ) (Fig.5). Similar acumulation of metabolites [alkalinity $\left(\approx \mathrm{HCO}_{3}{ }^{-}\right.$) and $\mathrm{NH}_{4}{ }^{+}$] and depletion of $\mathrm{e}^{-}$ 
acceptors (e.g. $\mathrm{SO}_{4}{ }^{2-}$ ) have previously only been found in eutrophic environments or very deep in sediments (Jørgensen 1989, Klump \& Martens 1989, Jørgensen et al. 1990). Although the concentration of metabolites in the farm sediment declined during winter, the overall level remained higher in spring than at the control station. The solute profiles at the latter station were similar to those previously reported from other coastal sediments (Jørgensen 1989, Mackin \& Swider 1989, Lerat et al. 1990).

Organic matter decomposition in sediments is to a large extent controlled by the quality of the organic material under decay (Westrich \& Berner 1984, Kristensen \& Blackburn 1987, Canfield 1989). The C:N ratio of bulk organic matter has often been used as a quality criteria (Blackburn 1986, Lerat et al. 1990). It is more realistic, however, to follow the $\mathrm{C}: \mathrm{N}$ ratio of the organic matter actually being decomposed since most organic matter in sediments is relatively refractory (Kristensen \& Blackburn 1987, Mackin \& Swider 1989). Andersen \& Kristensen (1988) suggested that the ratio between $\mathrm{TCO}_{2}$ and $\mathrm{NH}_{4}{ }^{+}$in the pore water is a measure of the net $\mathrm{C}: \mathrm{N}$ ratio of the organic matter being degraded in the sediment. The rationale is that carbon and nitrogen are regenerated and released in a ratio comparable to the organic matter actually decomposed in the sediment. The slope of the $\mathrm{TCO}_{2} / \mathrm{NH}_{4}{ }^{+}$regression line can only be expected to reflect the $\mathrm{C}: \mathrm{N}$ ratio of detritus used when (1) the removal of $\mathrm{TCO}_{2}$ and $\mathrm{NH}_{4}{ }^{+}$by diffusion is equal to the production during decomposition and (2) the sediment diffusion coefficients of $\mathrm{TCO}_{2}$ and $\mathrm{NH}_{4}{ }^{+}$are similar. The first assumption is fulfilled at steady state, which in the short term is likely to occur in the present sediments. However, the long-term temporal changes in process rates may be responsible for the variation found at different time of the year. The second assumption is fulfilled in these 2 sediments on the basis of an average temperature of $15^{\circ} \mathrm{C}$ and a porosity of $0.8\left[\mathrm{D}_{\mathrm{s}}\left(\mathrm{HCO}_{3}{ }^{-}\right)=5.9 \times 10^{-6} \mathrm{~cm}^{2} \mathrm{~s}^{-1}\right.$ and $\mathrm{D}_{\mathrm{s}}\left(\mathrm{NH}_{4}{ }^{+}\right)=5.0$ to $5.5 \times 10^{-6} \mathrm{~cm}^{2} \mathrm{~s}^{-1}$ (adsorption coefficient $K=0.8-1$ )] (Ullman \& Aller 1982).

The $C: N$ ratio of organic waste originating from the fish farm ranged from 5.7 to 7.0 [based on material collected during $24 \mathrm{~h}$ in a trap (placed under the net cage in summer) and the composition of food pellets], whereas the $C: N$ ratio for sediment underlying net cages ranged from 7.5 to 9.0. Although no input of wastes from the fish farm occurred at the control station, the $\mathrm{C}: \mathrm{N}$ ratio was only slightly higher, 7.7 to 9.8 . The ratio between alkalinity $\left(\mathrm{HCO}_{3}{ }^{-}\right.$) and $\mathrm{NH}_{4}{ }^{+}$(corrected for adsorption) in the pore water attained low $C: N$ ratios: 2 to 3 in the fish farm sediment and 3 to 5 in the control (Fig. 7). This clearly indicated preferential regeneration of nitrogen at both stations. The high input of proteinaceous material at the fish farm station was evident from the very low $\mathrm{C}: \mathrm{N}$ ratio in the pore water. Even in spring, where no significant difference in organic content between the 2 stations was apparent, the fish farm sediment exhibited a low C:N ratio the pore water. This indicates that remains of organic waste from the fish farm was still a major substrate for decomposers several months after termination of farming. In an estuarine sediment which was relatively unaffected by anthropogenic input of organic matter, Andersen \& Kristensen (1988) found a C:N ratio of 5.6 for the pore water metabolites. This corresponds to that of the present control station, and is representative for sediments under normal sedimentation regimes.

The flux ratio of 7 to 13 for the efflux of dissolved $\mathrm{CO}_{2}$ and DIN at Stn 1 and 19 to 48 at Stn 2 indicates a significant efflux of carbon or a net loss of nitrogen when the fluxes are assumed to be controlled by diffusion. These figures are considerably higher than the $\mathrm{C}: \mathrm{N}$ of both the bulk organic and dissolved inorganic pool in the sediment. Relatively low DIN fluxes (com-
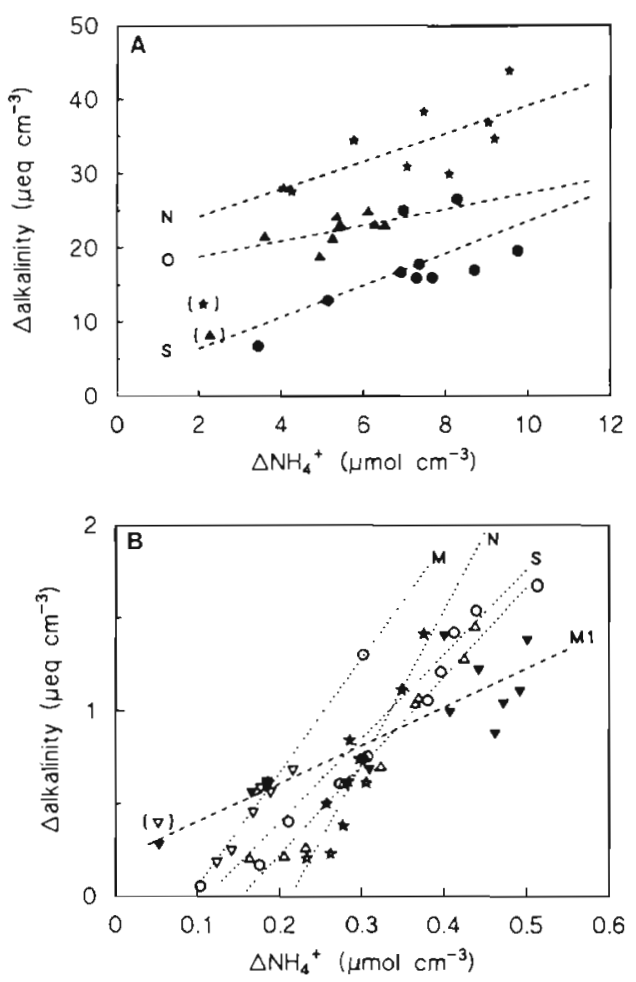

Fig. 7. (A) Relationship between pore water alkalinity ( $\triangle$ alkalinity) and ammonium $\left(\Delta \mathrm{NH}_{4}{ }^{+}\right)$at Stn 1 . Broken lines represent best fit by linear regression at each sampling date. Sep ( $\mathrm{S}$, $\bullet): y=2.06+2.15 x, r^{2}=0.74 ;$ Oct $(O, 4): y=16.64+1.07 x, r^{2}$ $=0.80 ; \operatorname{Nov}(\mathrm{N}, \star): \mathrm{y}=20.50+1.87 \mathrm{x}, \mathrm{r}^{2}=0.81$. (B) As in (A) at Stn 2 (September to March) and March at Stn 1. Sep $(S, 0): y=$ $-0.51+4.52 \mathrm{x}, \mathrm{r}^{2}=0.88 ;$ Oct $(0, \Delta): \mathrm{y}=-0.74+4.80 \mathrm{x}, \mathrm{r}^{2}=$ $0.97 ; \operatorname{Nov}\left(N\right.$, 解: $\mathrm{y}=-1.80+8.44 \mathrm{X}, \mathrm{I}^{2}=0.88 ; \operatorname{Mar}(\mathrm{M}, \nabla): \mathrm{y}=$ $-0.57+6.17 \mathrm{x}, \quad \mathrm{r}^{2}=0.74 ;$ Mar $(\operatorname{Stn} 1)(\mathrm{M} 1, \mathbf{\nabla}): \mathrm{y}=$ $0.20+2.06 x, r^{2}=0.74$ 
pared to Redfield ratios) are generally found in a wide variety of marine sediments (Andersen \& Kristensen 1988, Mackin \& Swider 1989, Kelly unpubl.). Several mechanisms behind this stoichiometric discrepancy have been suggested. (1) Denitrification, which is an important nitrogen removing process in sediments (Seitzinger et al. 1984, Jensen et al. 1988, Jensen et al. 1990), may be responsible for the difference between pore water pools and fluxes of inorganic $\mathrm{C}$ and $\mathrm{N}$ compounds. (2) Decomposition kinetics and stoichiometry may change temporally if the deposited organic matter is of variable origin and composition (Kelly unpubl). (3) Significant amounts of nitrogen can escape as DON (not measured in our study) (Holby 1991). At the present location the high flux-ratio at the control station is probably largely the result of denitrification due to the relatively oxidized conditions inducing a tight coupling of nitrification/denitrification (Jenkins \& Kemp 1984j. In the farm sediment, where no $\mathrm{O}_{2}$ and $\mathrm{NO}_{3}{ }^{-}$was present, temporal changes and DON release may be responsible for the discrepancy between $\mathrm{C}: \mathrm{N}$ ratio in pools and fluxes. However, a significant efflux of DOC might well occur and further studies are necessary to clarify the discrepancy.

\section{CONCLUSIONS}

This study showed that metabolism is an order of magnitude higher in sediment underlying net cages compared to a control site and to rates measured in unaffected coastal areas. The physical and chemical environment was altered towards a very reduced and sulfidic sediment, and no macrofauna was present. Particulate organic waste was degraded through anaerobic microbial processes, and the biogeochemical cycling of elements was very rapid in the eutrophic fish farm sediment. The release of reduced mineralization products (oxygen demanding substances and nutrients) contributed significantly to the eutrophication effects caused by the farm.

A high seasonal variation in fish farm sediment metabolism was seen and temperature alone could not explain these changes. It appears that seasonal alterations of the production scheme in the farm (food input) played an important role. During the farming season sulfate reduction rates in the upper 0 to $4 \mathrm{~cm}$ of $f$ arm sediment was very high and in these high metabolic layers, reduced label was mainly recovered in the AVS pool. When mineralization rates declined the CRS pool became more important.

Based on the concentration of mineralization products in the pore water and the $\mathrm{C}: \mathrm{N}$ ratios of the bulk of organic matter in the fish farm sediment a preferential nitrogen mineralization is found throughout fall and early spring.
Acknowledgements. We thank the staff at the Fiskegruppen Lillebælt fish farm for kind assistance during sampling and for providing data on water chemistry and fish production. $M$. $H$. was supported by Grant no. 36/306-1862, Odense University.

\section{LITERATURE CITED}

Andersen, F., Kristensen, E. (1988). The influence of macrofauna on estuarine benthic community metabolism: a microcosm study. Mar. Biol. 99: 591-603

Armstrong, F. A. J., Stearns, C. R., Strickland, J. D. H. (1967). The measurement of upwelling and subsequent biological processes by means of the Technicon Autoanalyzer and associated equipment. Deep Sea Res. 14: 381-389

Aure, J., Stigebrandt, A. (1990). Quantitative estimates of the eutrophication effects of fish farming on fjords. Aquaculture 90: 135-156

Blackburn, T. H. (1986). Nitrogen cycle in marine sediments. Ophelia 26: 65-76

Blackburn, T H., Lund, B. А., Krom, M. D. (1988). C- and Nmineralization in sediments of earthen marine fishponds. Mar. Ecol. Prog. Ser. 44: 221-227

Boudreau, B. P., Westrich, J. T (1984). The dependence of bacterial sulfate reduction on sulfate concentration in marine sediments. Geochim. cosmochim. Acta 48: $2503-2516$

Brown, J. R., Gowen, R. J., McLusky, D. S. (1987). The effect of salmon farming on the benthos of a Scottish sea loch. J. exp. mar. Biol. Ecol. 109: 39-51

Canfield, D. E. (1989). Sulfate reduction and oxic respiration in marine sediments: implications for organic carbon preservation in euxinic environments. Deep Sea Res. 36 (1): $121-138$

Chanton, J. P., Martens, C. S., Goldhaber, M. B. (1987). Biogeochemical cycling in an organic-rich coastal marine basin. 7. Sulfur mass balance, oxygen uptake and sulfide retention. Geochim. cosmochim. acta. 51: 1187-1199

Cline, J. D. (1969). Spectrophotometric determination of hydrogen sulfide in natural waters. Limnol. Oceanogr. 14: 454-458

Crill, P. M., Martens, C. S. (1987). Blogeochemical cycling in an organic-rich coastal marine basin. 6. Temporal and spatial variations in sulfate reduction rates. Geochim. cosmochim. Acta 51: 1175-1186

Edmond, J. M. (1970). High precision determination of titration alkalinity and total carbon dioxide content of sea water by potentiometric titration. Deep Sea Res. 17: $737-750$

Fossing, H., Jergensen, B. B. (1989). Measurement of bacterial sulfate reduction in sediments: evaluation of a single-step chromium reduction method. Biogeochemistry 8: 205-222

Frid, C. L. J., Mercer, T S. (1989). Environmental monitoring of caged fish farming in macrotidal environments. Mar. Pollut. Bull. 20 (8): 379-383

Gowen, R. J., Bradbury, N. B. (1987). The ecological impact of salmonid farming in coastal waters: a review. Oceanogr. mar. Biol. A. Rev. 25: 563-575

Graf, G. (1987). Benthic response to the annual sedimentation pattern. In: Rumohr, J., Walger, E., Zeitzschel, B. (eds.) Seawater-sediment interactions in coastal water. SpringerVerlag, Berlin, p. 84-92

Håkansson, L., Ervik, A., Mäkinen, T., Møller, B. (1988). Basic concepts concerning assessments of environmental effects of marine fish farms. Nordic Council of Ministers. Nord 1988: 90, Copenhagen 
Hall, P. O. J., Anderson, L. G., Holby, O., Kollberg, S., Samuelsson, M. O. (1990). Chemical fluxes and mass balances in a marine fish cage farm. I. Carbon. Mar. Ecol. Prog. Ser 61: 61-73

Hansen, P. K., Pittman, K., Ervik, A. (1990). Effects of organic waste from marine fish farms on the seabottom beneath the cages. Int. Counc. Explor. Sea. Comm. Meet (Maricult. Comm.) F: 34: 1-8

Holby, O. (1991). Biogeochemical processes in fish farm deposits and Weddell Sea sediments. Ph.D. thesis, Univ, of Göteborg

Holby, O., Hall, P. O. J. (1991). Chemical fluxes and mass balances in a marine fish cage farm. II. Phosphorus. Mar. Ecol. Prog. Ser. 70: 263-272

Jenkins, M. C., Kemp, W. M. (1984). The coupling of nitrification and denitrification in two estuarine sediments. Limnol. Oceanogr. 29: 609-619

Jensen, M. H., Andersen, T. K., Sørensen, J. (1988). Denitrification in coastal bay sediment: regional and seasonal variation in Aarhus Bight, Denmark. Mar. Ecol. Prog. Ser. 48: $155-162$

Jensen, M. H., Lomstein, E., Sørensen, J. (1990). Benthic $\mathrm{NH}_{4}{ }^{+}$ and $\mathrm{NO}_{3}{ }^{-}$flux following sedimentation of a spring phytoplankton bloom in Aarhus Bight, Denmark. Mar. Ecol. Prog. Ser. 61: 87-96

Jørgensen, B. B. (1978). A comparison of methods for the quantification of bacterial sulfate reduction in coastal marine sediments. I. Measurement with radiotracer techniques. Geomicrob. J. 1 (1): 11-27

Jørgensen, B. B. (1982). Mineralization of organic matter in the sea bed - the role of sulphate reduction. Nature, Lond. 296: 643-645

Jørgensen, B. B. (1989). Sulfate reduction in marine sediments from the Baltic Sea-North Sea transition. Ophelia 31 (1): $1-15$

Jørgensen, B. B., Bang, M., Blackburn, T. H. (1990). Anaerobic mineralization in marine sediments form the Baltic SeaNorth Sea transition. Mar. Ecol. Prog. Ser. 59: 39-54

Jørgensen, B. B., Sørensen, J. (1985). Seasonal cycles of $\mathrm{O}_{2}$, $\mathrm{NO}_{3}{ }^{-}$and $\mathrm{SO}_{4}{ }^{2-}$ reduction in estuarine sediments: the significance of an $\mathrm{NO}_{3}{ }^{-}$reduction maximum in spring. Mar. Ecol. Prog. Ser. 24: 65-74

Kaspar, H. F., Hall, G. H., Holland, A. J. (1988). Effects of sea cage salmon farming on sediment nitrification and dissimilatory nitrate reductions. Aquaculture 70: 333-344

Kelly, J. R., Nixon, S. W. (1984). Experimental studies of the effect of organic deposition on the metabolism of a coastal marine bottom community. Mar. Ecol. Prog. Ser. 17: 157-169

Klump, J. V., Martens, C. S. (1989). The seasonality of nutrient regeneration in an organic-rich coastal sediment: kinetic modeling of changing pore-water nutrient and sulfate distributions. Limnol. Oceanogr. 34 (3): 559--577

Kristensen, E., Andersen, F. Ø. (1987). Determination of organic carbon in marine sediments: a comparison of two CHN-analyzer methods. J. exp. mar. Biol. Ecol. 109: 15-23

Kristensen, E., Blackburn, T. H. (1987). The fate of organic carbon and nitrogen in experimental marine sediment systems: influence of bioturbation and anoxia. J. mar. Res. 45: 231-257

Kuivila, K. M., Murray, J. W., Devol, A. H. (1990). Methane

This article was submitted to the editor production in the sulfate-depleted sediments of two marine basins. Geochim. cosmochim. Acta 54: 403-411

Lerat, Y., Lasserre, P., Corre, le P. (1990). Seasonal changes in pore water concentrations of nutrients and their diffusive fluxes at the sediment-water interface. J. exp. mar. Biol. Ecol. 135: 135-160

Mackin, J. E., Swider, K. T. (1989). Organic matter decomposition pathways and oxygen consumption in coastal marine sediments. J. mar. Res. 47: 681-716

Martens, C. S., Klump, J. V (1984). Biogeochemical cycling in an organic-rich coastal marine basin 4. An organic carbon budget for sediments dominated by sulfate reduction and methanogenesis. Geochim. cosmochim. Acta 48: $1987-2004$

Müller-Haekle, A. (1986). Control of water quality around a cage fish farm in the Norrby Archipelago (Northern Bothnian Sea). Vatten 42: 205-209

Ross, A. (1989). Marine fish farming - Scotland's pride or problem? Ecos 10 (3): 8-12

Sampou, P., Oviatt, C. A. (1991). Seasonal patterns of sedimentary carbon and anaerobic respiration along a simulated eutrophication gradient. Mar. Ecol. Prog. Ser. 72: 271-282

Samuelsen, O. B., Ervik, A. S., Solheim, E. (1988). A qualitative and quantitative analysis of sediment gas and diethylether extract of the sediment from salmon farms. Aquaculture 74: 277-285

Seitzinger, S. P., Pilson, M. E., Nixon, S. W. (1984). Denitrification and nitrous oxide production in a coastal marine ecosystem. Limnol. Oceanogr. 29: 73-83

Skyring, G. W. (1987). Sulfate reduction in coastal ecosystems. Geomicrob. J. 5 (3/4): 295-374

Solarzano, L. (1969). Determination of ammonia in natural waters by the phenolhypochlorite method. Limnol. Oceanogr. 14: 799-801

Swider, K. T., Mackin, J. E. (1989). Transformations of sulfur compounds in marsh-flat sediments. Geochim. cosmochim. Acta 53: 2311-2323

Talling, F. (1973). The application of some electrochemical methods to the measurement of photosynthesis and respiration in fresh water. Freshwat. Biol. 3: 335-362

Thode-Andersen, S., Jørgensen, B. B. (1989). Sulfate reduction and the formation of ${ }^{35} \mathrm{~S}$-labeled $\mathrm{FeS}, \mathrm{FeS}_{2}$, and $\mathrm{S}^{0}$ in coastal marine sediments. Limnol. Oceanogr. 34 (5): $793-806$

Troelsen, H., Jørgensen, B. B. (1982). Seasonal dynamics of elemental sulfur in two coastal sediments. Estuar. coast. Shelf Sci. 15: 255-266

Ullman, W. J., Aller, R. C. (1982). Diffusion coefficients in nearshore marine sediments. Limnol. Oceanogr. 27 (3): $552-556$

Westrich, J. T., Berner, R. A. (1984). The role of sedimentary organic matter in bacterial sulfate reduction: the $G$ model tested. Limnol. Oceanogr. 29 (2): 236-249

Westrich, J. T., Berner, R. A. (1988). The effect of temperature on rates of sulfate reduction in marine sediments. Geomicrob. J. 6: 99-117

Ye, L-X., Ritz, D. A., Fenton, G. E., Lewis, M. E. (1991). Tracing the influence on sediments of organic waste from a salmonid farm using stable isotope analysis. J. exp. mar. Biol. Ecol. 145: 161-174

Manuscript first received: August 23, 1991

Revised version accepted: January 13, 1992 